\title{
Physical characteristics, categories and functions of song in the Indian Robin Saxicoloides fulicata (Aves: Muscicapidae)
}

\section{Anil Kumar}

High Altitude Regional Centre, Zoological Survey of India, Solan, Himachal Pradesh 173211, India Email: anil_rathi@yahoo.com, anilsonta@gmail.com

Date of publication (online): 26 July 2011 Date of publication (print): 26 July 2011 ISSN 0974-7907 (online) | 0974-7893 (print)

\section{Editor: Aziz Aslan}

\section{Manuscript details:}

Ms \# o2630

Received 19 November 2010

Final received 31 May 2011

Finally accepted 30 June 2011

Citation: Kumar, A. (2011). Physica characteristics, categories and functions of song in the Indian Robin Saxicoloides fulicata (Aves: Muscicapidae). Journal of Threatened Taxa 3(7): 1909-1918

Copyright: (c) Anil Kumar 2011. Creative Commons Attribution 3.0 Unported License. JoTT allows unrestricted use of this article in any medium for non-profit purposes, reproduction and distribution by providing adequate credit to the authors and the source of publication.

Author Details: DR. ANIL KUMAR is a scientist in ZSI, Solan. Over the years his research work is focused on communication of birds. So for, he has recorded over 200 avian species mainly from Himalaya and contributed over 30 research papers/ articles. For ZSI, he has worked on some departmental research projects pertaining to mainly faunal studies.

Acknowledgements: I am grateful to Director ZSI, Kolkata for his kind encouragement and support. I am grateful to Director, Wildlife Institute of India, Dehradun, for encouraging and extending me institutional facilities during the course of study. I am thankful to Dr. Ajeet Singh (Haridwar), Dr. Romesh Kumar Sharma (Haridwar), Dr. Himmat Singh (Jodhpur), and Dr. Rajah Jayapal (WII) for their cooperation at various levels during the study. Financia support from DST under SERC Fast Track scheme (Project no. SR/FTP/LS-166/2000) is also gratefully acknowledged. Special thanks are due to Shri Anand Arya (Noida) for providing a nice image of Indian Robin.
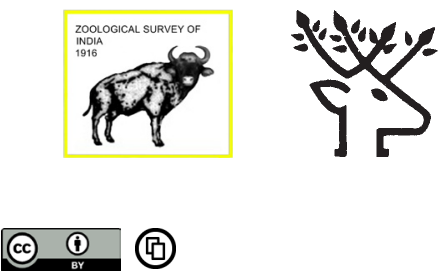

OPEN ACCESS | FREE DOWNLOAD
Abstract: The physical characteristics and biological significance of song in the endemic Indian Robin Saxicoloides fulicata are described. Songs are discrete and composed of strophes (structural units) with frequency ranging from 1.03 to $8.00 \mathrm{kHz}$, preceded and followed by temporal intervals from 0.21 to $21.25 \mathrm{sec}$. Occasional, monosyllabic whistles are also identified. In a song bout usually the same type of strophe is repeated several times in a stereotyped manner with minor structural variations of elements before switching to another type of strophe. Most strophes are composed of two to five elements, having both simple and complex structure. Two categories of songs have been identified on the basis of their acoustical features and context of production. Type-A songs are simple, stereotyped, spontaneous and common, while type-B songs are rare, female-oriented and more complex than type-A. Song is used in both inter- and intrasexual contexts. It seems that type-A songs are driven by male-male competition for territory and mates. Males also shorten the length of strophes and reduce gaps between strophes (in type-B songs) on the arrival of females in the vicinity, most probably to increase the song rate, suggesting it to be an indicator of male quality.

Key words: Indian Robin, Saxicoloides fulicata, song organisation, song characteristics, song function.

Hindi Abstract: स्थानीय कलचिड़ि में गायन की विशेषताओं तथा उसके जैविक महत्व का उल्लेख किया गया है। गायन छंदो (संरचनात्मक ईकाई) से बना, 0.21 से 21.25 सेकेंड के कालान्तरो से विभक्त, अनिरंतर प्रकार का था जिसकी ध्वनी आवृत्ति 1.03 से 8.00 किलो हर्त्ज के मध्य थी। एकल शब्दांशीय, आकस्मिक सिटियॉ भी पायी गयी। एक गायन अवधि में, एक छंद से दूसरे छंद पर जाने से पहले, अंशो मे निहित छोटे-छोटे अंतरो के साथ, साधारणत्या एक प्रकार के छंद को बारम्बार प्रयोग किया गया। अधिकांश छंद दो से लेकर पॉच अंशों से बने थे, तथा सरल एंवम जटिल दोनों प्रकार की संरचना वाले थे। ध्वनी विशेषताओं तथा उपयोग के संदर्भ में, गायन को दो वर्गो में विभक्त किया गया। वर्ग 'अ' का गायन सरल, रूढ़िबद्ध, स्वत् स्फूटित तथा सहज था जबकि वर्ग 'ब' का गायन दुर्लभ, मादा उन्मुख तथा अधिक जटिल था। इस शोध में, कलचिड़ि ने गायन को अर्न्तजातिय तथा सजातिय दोनों संदर्भो में प्रयोग किया। ऐसा प्रतीत होता है कि वर्ग 'क' का गायन क्षेत्र रक्षण तथा मादा प्राप्ति हेतू, नर नर प्रतिद्धन्दिता के परिणाम स्वरूप उत्पन्न हुआ। नरो ने मादा के निकट आने पर, संभवत्या गायन की तीर्वता को बढ़ाने के लिये, गायन में छंदो की लम्बाई को लघु कर दिया तथा उनके मघ्य कालान्तर को भी संकुचित कर दिया (वर्ग 'ब' का गायन) जो कि नर उत्कृष्टता का द्योतक हो सकता हैं।

\section{INTRODUCTION}

Mate acquisition and male-male competition are responsible for the evolution of song in passerine birds (Catchpole \& Slater 1995). Song characteristics such as acoustical features, mode of production, temporal patterns and structural complexity (variability of elements) are highly diverse among oscine birds (Marler \& Slabbekoorn 2004). Many passerine species sing two categories of songs that differ in their patterns of temporal, spatial and contextual use (Spector 1992). The first category songs are often simple and highly stereotyped, sung at relatively low rates. In contrast, second category songs are usually more complex and variable, and sung at higher rates (Highsmith 1989; Kroodsma et al. 1989; Staicer 1989; Bolsinger 2000). Studies on the functions of song (with some exceptions) suggest that type-A songs (more stereotyped) are used as intersexual signals, while type-B (more variable) are used 
intrasexually (Kroodsma 1981; Spector 1992; Bay 1999). Mode of singing also varies in birds. Mostly oscine birds use two types of singing mode i.e., 'repeat' or 'eventual variety' (singer produces one song type/ strophe repeatedly before switching to another type of strophe), and 'serial' or 'immediate variety' mode (singer produces a variety of song strophes/ phrases without any apparent rule) (Molles \& Vehrencamp 1999).

In many species song repertoire is organised around a limited number of strophes or song types, such as in the White-crowned Sparrow Zonotrichia leucophrys, where each male uses only a single, simple, monotonous song in stereotyped manner (Baptista 1975). Some other species, namely European Redwing Turdus iliacus (Bjerke \& Bjerke 1981), Splendid Sunbird Necterina coccinigastra (Grimes 1974) and Ovenbird Seiurus aurocapillus (Falls 1978) are also known for their small repertoire size. While in others, such as in Mokingbird Mimus polyglottos (Howard 1974) and Sedge Warbler Acrocephalus schoenobaenus (Kroodsma \& Parker 1977; Catchpole 1976), the songs composed of a large number of dissimilar structured song elements with an unrestricted number of combinations (Catchpole \& Slater 1995).

Robins belong to old world Chats-Flycatchers (Muscicapidae) with some exceptions; the American Robin Turdus migratorius and Mountain Robin T. plebejus belong to family Turdidae, the Scarlet Robin Petroica multicolor belongs to the family Petroicidae (del Hoyo et al. 2006). Robins use both simple and complex vocalisations for communication (Bhatt et al. 2000; Kumar \& Bhatt 2001). For example, European Robin Erithacus rubecula use a complex, melodious song (made up of prolonged notes, short warbles and trills) for territory defence, almost throughout the year (Hoelzel 1986, 1989; Scriba \& Goymann 2010). African Forest Robins (Stiphrornis) have been reported to use two types of vocalisations (Beresford \& Cracraft 1999). However, functions of these categories remain unclear. Similar patterns of vocalisations were also reported in a recently discovered species of African Robin, the Olive-backed Forest Robin Stiphrornis pyrrholaemus (Schmidt et al. 2008). Oriental Magpie Robin Copsychus saularis also use two distinct categories of songs, which differ in structure and functions (Bhatt et al. 2000; Kumar 2003).

The Indian Robin Saxicoloides fulicata

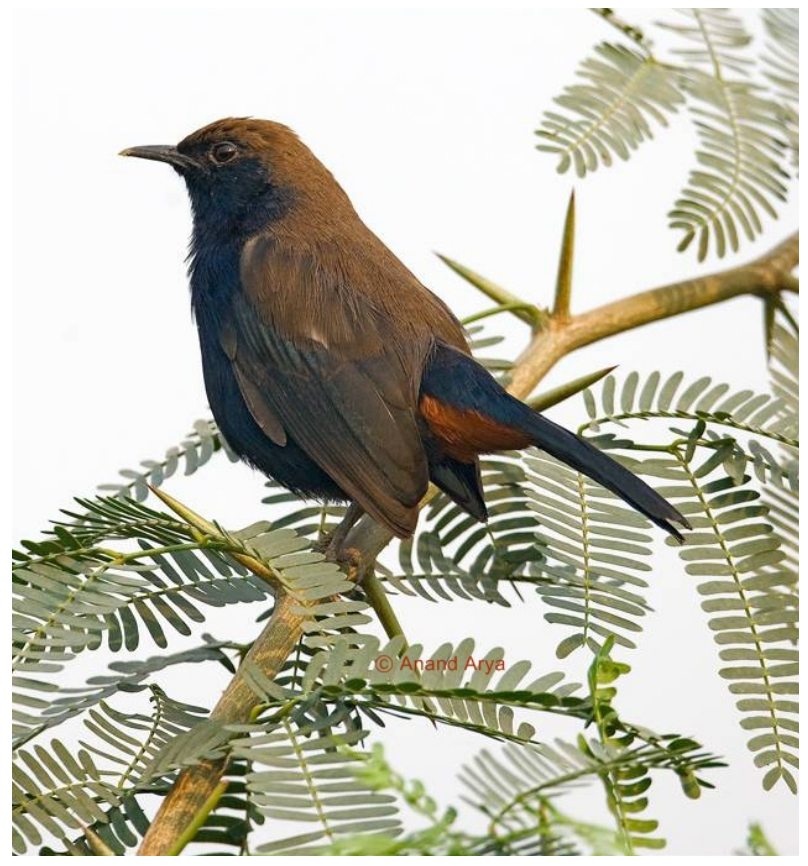

Image 1. Indian Robin Saxicoloides fulicata

(Muscicapidae) is an endemic, small-sized $(19 \mathrm{~cm})$, passerine species, distributed throughout the Indian subcontinent except northeastern, higher Himalaya and Thar Desert, and is divided into a few races. It is a common, resident, territorial and sexually dimorphic bird. Males have glossy black under parts and a white shoulder patch (Image 1), while females have grayishbrown upperparts and grayish under parts and lack white shoulder patch. It prefers dry, stony areas with sparse scrub, arid stony ridges, low rocky hills outcrops, edges of cultivation and deserted buildings, gardens and groves (Ali \& Ripley 1983; Grimmett et al. 1998). Information is scanty on the singing behaviour \& sociobiology of the species (Nirmala \& Vijayan 2003). In this article, I describe and quantify the organisation of song in terms of physical characteristics, categories and context of production in the Indian Robin for the first time.

\section{METHODS}

\section{Field recordings}

Songs of 23 male Indian Robin were recorded in their natural habitat from four different places in northern India. Recordings on 11 individuals were made in Dehradun ( $\left.30^{\circ} 26^{\prime} \mathrm{N} \& 7^{\circ} 06^{\prime} \mathrm{E}\right)$ during May 2002 to February 2005; during the same period, five 


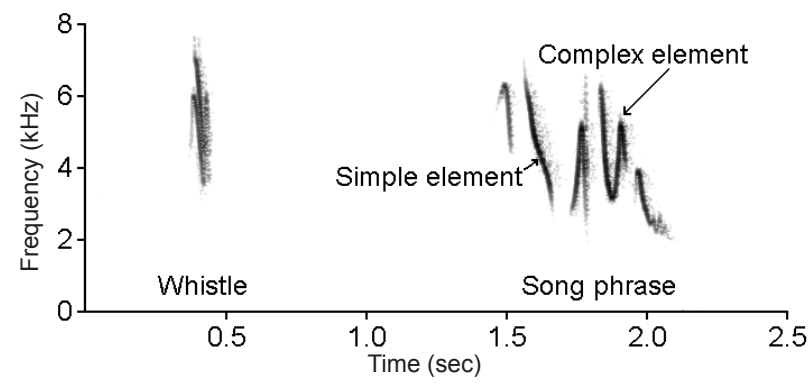

Figure 1. Song components and terminology used in the present study.

birds were recorded at Srinagar, Garhwal $\left(30^{\circ} 21^{\prime} \mathrm{N}\right.$ \& $\left.78^{0} 77^{\prime} \mathrm{E}\right)$; two at Haridwar $\left(29^{\circ} 55^{\prime} \mathrm{N} \& 7^{\circ} 08^{\prime} \mathrm{E}\right)$; and five recordings in and around Jodhpur $\left(26^{0} 21^{\prime} \mathrm{N}\right.$ $\left.\& 73^{\circ} 06^{\prime} \mathrm{E}\right)$ during March-April 2001. All birds recorded were unbanded. To avoid recording the same individual twice, each bird was recorded only when it was within view and recordings were made in each area only once. A total of 183 recordings (2-9 per individual) were made ranging 2-14 minutes duration. Signals were recorded using Sony CFS 1030S or Sony PCM-M1 or Marantz PMD 222 sound recorders and JVC MZ-500 or Sennheiser ME-66 microphones. Behavioural correlates were used to infer the possible meaning of the song.

\section{Data analysis}

Recordings were digitised using M-Audiophile 2496 (sound card) at the sampling rate $48 \mathrm{kHz}$ and 16 bit resolution. After editing, cuts of high quality recordings (excluding recordings of five individuals due to poor quality) were analyzed with the help of windows based sound analysis software, Avisoft SAS Lab Pro (version 4.1). Spectrograms were displayed on a computer monitor and measurements of variables were made using frequency and time courser. Dominant frequency of given strophe was analysed generating power spectrum. The frequency of highest peak was recorded. For the sequential analysis of strophes, spectrograms were printed using several line mode. In this mode, about $40 \mathrm{sec}$ long recording was printed in seven lines on A4 size paper in landscape page setup. All spectrograms were calculated using following setting of SAS Lab: 512 FFT-length, 75\% Frame, Hanning window and $87.5 \%$ time window overlap. In the present study, minimum and maximum frequency, frequency bandwidth, dominant frequency (frequency of maximal amplitude), duration and intervals in song strophes were measured. Number and types of elements per strophe, song rate (strophes per minute) and complexity level (types of elements per min.) were calculated to define the acoustical features of songs. Results were expressed as mean \pm SE. Nonparametric statistics was used to measure the level of significance in differences, since most data were not normally distributed. Windows based software SPSS was used for the analysis.

\section{Song terminology}

Study of literature reveals that there is no standardization of terminology for the songs of different species. Indeed, different authors used different terms for the same songs features (Spector 1992). I labeled structural units of song on the basis of morphological features, using terminology partly adopted from literature (Staicer 1989; Bay 1999). The song in Indian Robin consists of a number of distinct sections, called strophes or phrases and each strophe consists of several smaller units known as elements (Fig. 1). An element is a short tracing on the spectrogram. On the basis of frequency modulations the elements can further be classified into simple (constant pitch, un-modulated or slightly modulated frequency) and complex (varied pitch, rapidly modulated or multi harmonic frequency) elements. In a song bout, in different phrases, often bird use a combination of one to three elements together and is named as a syllable (Catchpole \& Slater 1995).

\section{RESULTS}

\section{Physical characteristics}

Males sang during the breeding season mostly in the morning (0500-0900 hrs) and evening (1700-1730 hrs). Individuals were observed singing from exposed branches of trees, rocks, walls, electric wires and on the ground. The song of Indian Robin was composed of strophes with occasional whistles (Fig. 2). The strophes were made up of one to nine elements, with dissimilar structure and occasional repetition of elements. The frequency of song ranged from 1.03 to $8.00 \mathrm{kHz}$. Dominant frequency of most songs was 4.2 $\mathrm{kHz}(2.3-6.5 \mathrm{kHz})$. Average duration of strophes was $0.68 \pm 0.03$ to $0.21 \pm 0.02$ sec. preceded and followed by temporal intervals ranging $6.34 \pm 0.46$ to $0.61 \pm 0.03$ 
Table 1. Physical characteristics and temporal variations in two categories of songs in the Indian Robin.

\begin{tabular}{|c|c|c|c|c|c|}
\hline Variables & Song type-A (Mean \pm SE) & Song type-B (Mean $\pm S E)$ & $\begin{array}{l}\text { Mann-Whitney } \\
\text { U-test }\end{array}$ & Z-Score & $\begin{array}{c}\text { Probability } \\
\text { P }\end{array}$ \\
\hline Minimum frequency $(\mathrm{kHz})$ & $\begin{array}{c}2.48 \pm 0.05 \\
(1.87-3.53, N=18, n=64)\end{array}$ & $\begin{array}{c}2.19 \pm 0.11 \\
(1.03-4.34, N=8, n=48)\end{array}$ & 1169.00 & -2.16 & 0.031 \\
\hline Maximum frequency $(\mathrm{kHz})$ & $\begin{array}{c}6.96 \pm 0.07 \\
(5.43-8.00, N=18, n=64,)\end{array}$ & $\begin{array}{c}6.22 \pm 0.14 \\
(4.31-7.65, N=8, n=48)\end{array}$ & 900.00 & -3.74 & 0.001 \\
\hline Frequency Bandwidth (kHz) & $\begin{array}{c}4.48 \pm 0.08 \\
(2.87-6.00, N=18, n=64) \\
\end{array}$ & $\begin{array}{c}4.03 \pm 0.09 \\
(2.88-5.87, N=8, n=48)\end{array}$ & 955.50 & -3.41 & 0.001 \\
\hline Dominant frequency $(\mathrm{kHz})$ & $\begin{array}{c}4.21 \pm 0.08 \\
(3.44-6.50, N=18, n=64)\end{array}$ & $\begin{array}{c}4.20 \pm 0.15 \\
(2.30-6.35, N=8, n=48)\end{array}$ & 1502.50 & -0.20 & $0.844^{*}$ \\
\hline Strophe duration (sec) & $\begin{array}{c}0.68 \pm 0.03 \\
(0.24-2.16, N=18, n=64)\end{array}$ & $\begin{array}{c}0.21 \pm 0.02 \\
(0.05-0.64, N=8, n=48)\end{array}$ & 125 & -8.30 & 0.001 \\
\hline Inter-strophe interval (sec) & $\begin{array}{c}6.34 \pm 0.46 \\
(2.17-21.25, N=18, n=64)\end{array}$ & $\begin{array}{c}0.61 \pm 0.03 \\
(0.21-1.29, N=8, n=48)\end{array}$ & 0.00 & -9.00 & 0.001 \\
\hline $\begin{array}{l}\text { Song Rate } \\
\text { (Strophes per min) }\end{array}$ & $\begin{array}{c}9.33 \pm 0.67 \\
(6.00-14.00, N=12, n=15)\end{array}$ & $\begin{array}{c}70.56 \pm 3.71 \\
(54.00-84.00, N=6, n=9)\end{array}$ & 0.00 & -4.04 & 0.001 \\
\hline No. of elements per strophe & $\begin{array}{c}5.81 \pm 0.22 \\
(1.00-9.00, N=18, n=64)\end{array}$ & $\begin{array}{c}2.17 \pm 0.11 \\
(1.00-4.00, N=8, n=48)\end{array}$ & 67.00 & -8.75 & 0.001 \\
\hline Types of elements per strophe & $\begin{array}{c}4.73 \pm 0.18 \\
(1.00-9.00, N=18, n=64)\end{array}$ & $\begin{array}{c}1.47 \pm 0.11 \\
(1.00-3.00, N=8, n=48)\end{array}$ & 93.00 & -8.66 & 0.001 \\
\hline $\begin{array}{l}\text { Song complexity (Types of } \\
\text { elements per min) }\end{array}$ & $\begin{array}{c}9.18 \pm 1.22 \\
(4.00-24.00, N=9 n=16)\end{array}$ & $\begin{array}{c}21.36 \pm 1.31 \\
(16.00-29.00, N=5, n=11)\end{array}$ & 8.50 & -3.93 & 0.001 \\
\hline
\end{tabular}

* Not significant; Ranges are given in parenthesis with number of individuals $(\mathrm{N})$ and number of song/strophe samples $(\mathrm{n})$.

Table 2. Some examples of sequence of phrases in song bouts in the Indian Robin. For example, bird D1 used two types of phrases i.e. a and b, alternatively in 5 minutes long bout, and bird J1 used six types of phrases almost randomly.

\begin{tabular}{|c|c|c|c|c|c|c|c|}
\hline \multirow{2}{*}{$\begin{array}{l}\text { Locations of the } \\
\text { recordings }\end{array}$} & \multirow{2}{*}{ Bird ID } & \multicolumn{5}{|c|}{ Sequence of phrases in $\mathbf{5}$ min. song duration } & \multirow{2}{*}{$\begin{array}{l}\text { Types of } \\
\text { phrases }\end{array}$} \\
\hline & & 1 & 2 & 3 & 4 & 5 & \\
\hline \multirow{3}{*}{$\begin{array}{l}\text { Dehradun } \\
\left(30^{\circ} 26^{\prime} N \& 78^{\circ} 06^{\prime} E\right)\end{array}$} & D1 & \multicolumn{5}{|c|}{ aabababbbbabaaaaabbbbbaaaaabbabababaaaaabbbb $>$..bbbbbb $>$ aaaaa } & 2 \\
\hline & $\mathrm{D}^{*}$ & \multicolumn{5}{|c|}{ abccdefcgcdhaaeddiddaeaadddiddaaeddiaadejdaakddekddialadedmnlddm } & 13 \\
\hline & D2 & \multicolumn{5}{|c|}{ aaaaaaaaaaаaаaаaа...аaаaаaаaаa...aaaa $\gg$ bbbbbbbbbbbb $\gg$ aaaabbbb } & 2 \\
\hline \multirow{2}{*}{$\begin{array}{l}\text { Srinagar, Garhwal } \\
\left(30^{\circ} 21^{\prime} \mathrm{N} \& 78^{\circ} 77^{\prime} \mathrm{E}\right)\end{array}$} & $\mathrm{S} 1$ & \multicolumn{5}{|c|}{$\mathrm{aa} \gg \mathrm{b} \gg \mathrm{bbbbbb \ldots} \gg \ldots \gg$...aaaaacaaa...bbb $\gg$ aaaaa...bbbc } & 3 \\
\hline & S2 & \multicolumn{5}{|c|}{ aaaaaaaaaaaaaaaaaaaaaaaa...aaaaaa...bbbbbbb...aaaaa..bbaabbbbaaaaa } & 2 \\
\hline \multirow{2}{*}{$\begin{array}{l}\text { Jodhpur } \\
\left(26^{\circ} 21^{\prime} N \& 73^{\circ} 06^{\prime} E\right)\end{array}$} & $\mathrm{J} 1$ & \multicolumn{5}{|c|}{ aabac...bbb...abbbbbb...acadacacacdacaacacacef $\longrightarrow$ caacacbbbb $\gg \longmapsto$} & 6 \\
\hline & $\mathrm{J} 2$ & \multicolumn{5}{|c|}{ aaaaaa $\gg$ aaaa $\gg$ aaaaabbbbbbbbbbbb $\gg$ aaaaaaaaaaaaa $\gg$ bbbb } & 2 \\
\hline
\end{tabular}

Whistle; ... Longer intervals; * Song type-B (given time duration is not actual)

sec. Songs were produced at variable rate; $9.33 \pm 0.67$ strophes per minute in song type-A and $70.56 \pm 3.71$ strophes per minute in song type-B (Table 1).

Indian Robin sang in moderate sized song bouts ranging one to six minutes duration (sometimes $<1$ or $>6$ min). Different types of temporal patterns were identified. On the basis of sequence of strophes, three categories were observed. However, distinction is purely temporary and individuals do not follow strict rule in sequencing. Two to nine types of phrases with modulated frequency were identified in song bouts. However in most cases (74\%) males used two to three types of phrases. Occasional whistles were also observed. These were monosyllabic in structure and uttered 1-5 times between any two consequent phrases of a song bout.

\section{Stereotyped mode}

In many cases (58\%), the bird repeated a particular strophe in stereotyped order with minor structural variations of elements (Fig. 2A, element $g$ in $\mathrm{P} 1$ is replaced by $\mathrm{f}$ in $\mathrm{P} 2$ and elements $\mathrm{c}, \mathrm{d} \& \mathrm{e}$ showed variations in their minimum and maximum frequencies, respectively, and adding or deleting of an 

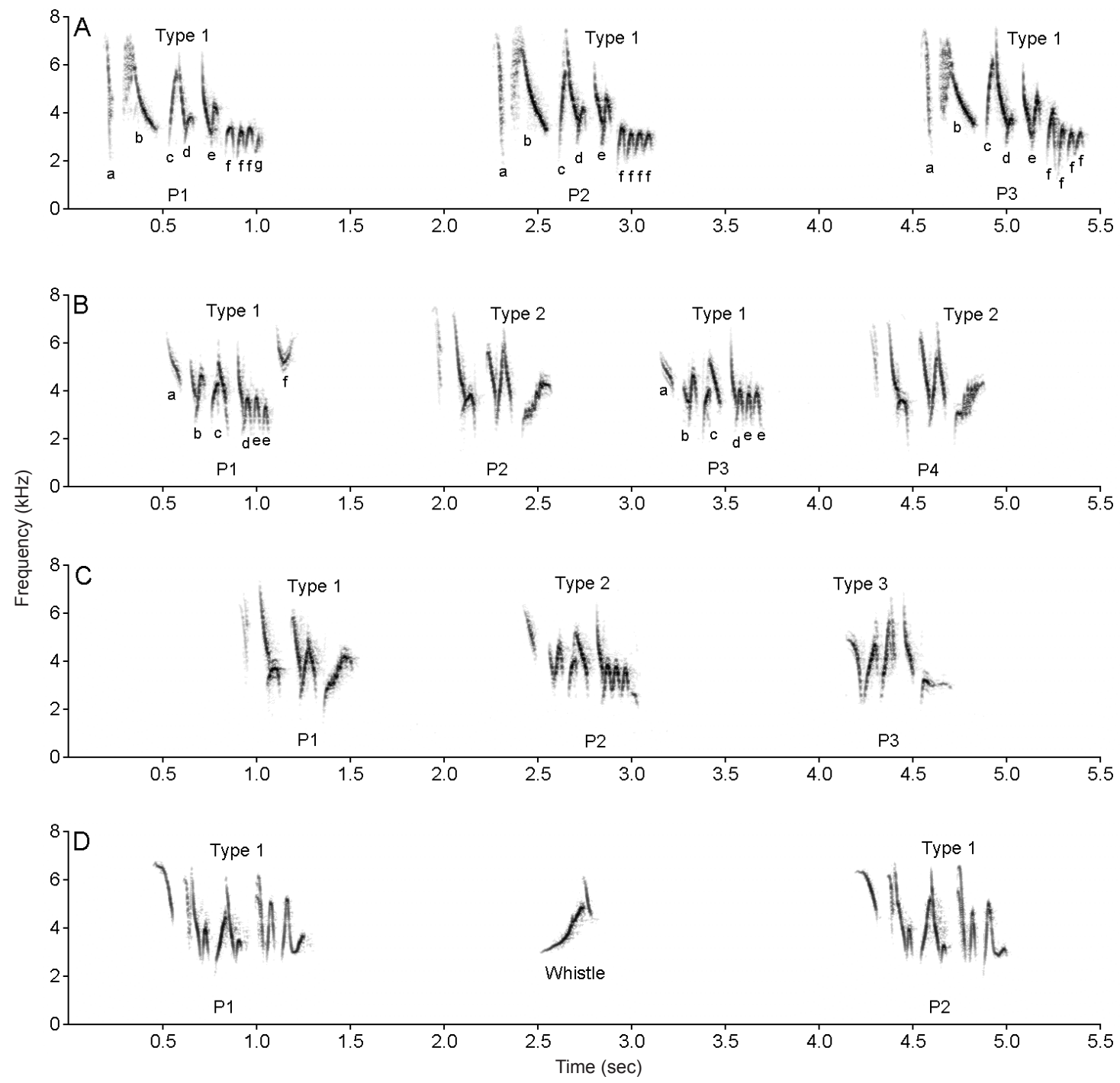

Figure 2. Temporal variations in the song of Indian Robin.

A - Stereotyped mode with minor structural variations in elements; B - Alternative mode with adding/ deleting of elements, such as element $f$ of $P 1$ is omitted in P3 phrase; C - Use of three different types of phrases in a given song bout; D - Use of whistles between phrases.

element, such as in Fig. 2B, element $\mathrm{f}$ of $\mathrm{P} 1$ is omitted in P3). This mode was observed mainly in isolated birds $(\mathrm{N}=9)$ with no conspecific neighbor.

\section{Alternative mode}

In this mode individuals produced two or three types of phrases in alternative manner (Fig. 2C). For instance, bird D1 (Table 2) produced a and b phrases alternatively and bird $\mathrm{J} 1$ produced $\mathrm{a}, \mathrm{b}, \mathrm{c}$ and $\mathrm{d}$ phrases alternatively without fixed number and sequence and new phrases such as e and $\mathrm{f}$, in a recording. In some recordings occasional whistles were also used between phrases (Fig. 2D). This mode of singing was observed only in birds $(\mathrm{N}=3)$ having conspecific neighbours.

\section{Complex mode}

Contrary to type-A songs in stereotyped mode (Fig. $3 \mathrm{~A})$, in some cases (16\%) such as type-B songs, birds produced large number of phrases randomly with out any strict order in sequence (Fig. 3B, C). However, repetition of phrases (such as in Fig. 3B and C, Type 1 repeated as P1, P5 and P7) and re-assortment of elements/ phrases (such as Type 2 as P2, P8 and P12 in Fig. 3B and C) were identified, for example type-B (Table 2) songs of bird D1. 



Figure 3. Song categories in the Indian Robin.

A - Type-A song in stereotyped mode; B \& C - Type-B song with 7 types of phrases with repetition of some phrases, such as type-1.

\section{Song categories and functions}

Syntactically two categories of songs were identified (Fig. 3). Type-A songs were common ( $84 \%$ of total songs recorded) in breeding season and consisted repeated strophes having $0.68 \pm 0.03 \mathrm{sec}$ duration and followed by $6.34 \pm 0.46 \mathrm{sec}$ gap. Usually, the bird repeated a particular strophe several times before switching to another strophe. These songs usually uttered during territory advertisement and to maintain pair-bond. However, territorial conflicts were not obvious $(n=5)$. This could be the result of low population densities of this species in northern India (pers. obs.; unpub. data). Mostly solitary pairs were observed in a particular area.

Type-B songs were more complex (Mann-Whitney U-test; $\mathrm{U}=8.5, \mathrm{p}<0.001$ ) and rare (only $16 \%$ of songs recorded) as compared to type-A songs. Most acoustical characteristics significantly differ (Table 1) from type-A songs except dominant frequency $(\mathrm{P}=0.844)$. Type-B songs were consisted of short strophes having 1-4 elements. The duration and gap of strophes were significantly lower $(p<0.001)$ then type-A songs. The males produced $70.56 \pm 3.71$ strophes per minute. These songs were observed only in the presence of females and during courtship. Courtship displays were also associated with these songs. During these displays male birds were observed running on the ground or on a wall 0.65 to $2.15 \mathrm{~m}$ towards a female with splayed and erected tail, forwarded beak and lowered head while emitting a complex song. Within a few seconds the male mounted the female for insemination.

\section{DISCUSSION}

\section{Physical characteristics}

In the present study, the Indian Robin used stereotyped songs, organised around a limited number of strophes (except type-B songs). Studies on temperate song birds provide some insights on how song output is organised. Like the Indian Robin, Chaffinch Fringilla coelebs use three or four song types (phrases) in its song, with a sequence of each in turn before returning to the first (Slater 1983). Sequence of song types is not 
always the same and the phrases are not necessarily sung with equal frequency. It is quite common in many species for one song to comprise a much larger part of the bird's output than another (Catchpole \& Slater 1995). Degree of song variability is highly diverse in birds and song characteristics may also vary temporally and spatially (Catchpole \& Slater 1995). Tawny Pipit Anthus campestris use short and simple songs (Osiejuk et al. 2007) and males are known to have single song type repertoire (Neuschultz 1986). In contrast, Chaffinch Fringilla coelebs, Great Tit Parus major, Ring Ousel Turdus torquatus and Dark-eyed Junco Junco hyemalis use several song types (Krebs et al. 1978; Slater 1981; Ince \& Slater 1985; Williams \& MacRoberts 1977), while others, like Red-eyed Vireo Vireo olivaceus and Marsh Wren Cistothorus palustris use 12 to $>100$ song types in their repertoire (Borror 1981; Kroodsma \& Verner 1987). Common Nightingale Luscinia megarhynchos have a large repertoire (up to 260 different song types) divided into whistle songs and nonwhistle songs (Kipper et al. 2004; Kunc et al. 2005).

In most oscine birds, song complexity serves as an honest signal of male quality (Hesler et al. 2011), and selection may also favour song parameters such as song rate and song length (Garamszegi \& Møller 2004; Kunc et al. 2005). In species with large repertoire, sexual selection might favour the evolution of structural song traits such as whistle songs in nightingales (Kunc et al. 2005), thought to be evolved to attract migrating females at night (as structurally simple whistles suffer less from spectral degradation during propagation over long distance; Slabbekoorn et al. 2002). While, in species with a small repertoire, it may favour song length and song rate, as reported in some species such as Willow Tit Parus montanus (Welling et al. 1997) and Hoopoe Upupa epops (Martiu-Vivaldi et al. 2002). In the present study, Indian Robin used song in both inter- and intra-sexual contexts. When inferred with the behavioral observations, type-A songs were driven by male-male competition for territory and mate acquisition. Males also shortened the length of strophes and reduced gap between strophes (in type-B songs) on the arrival of females in close vicinity, most probably to increase song rate, which could also be an indicator of male quality as suggested for other species.

The songs of Indian Robin range from 2.19 to 6.96
$\mathrm{kHz}$ frequencies. The dominant frequency (i.e. 4.2 $\mathrm{kHz}$ ) of songs was considerably higher then expected for its body weight. Wallschlager's regression function (Wallschlager 1980) of 'central frequency' on body weight predicts a frequency of $3.6 \mathrm{kHz}$ for birds having body weight (i.e. 18-19 g) like Indian Robin (Ali \& Ripley 1983). Similar trends have also been reported in some South American passerines (Ryan \& Brenowitz 1985). Lambrechts (1996) suggested that birds should have greater performance at about onefourth of their frequency range.

Indian Robin produced its song in three different modes. In stereotyped mode, in a song bout bird produced same phrase again and again (like ... AAAAA....), while, in alternative mode bird used two or three types of phrases (like ....AAA...BBBB... AAAA....BB....CCCC...). Third mode of production was complex and observed only in type-B songs. In the literature, singing mode refers to the sequential pattern of song type (strophes/ phrases) production (Molles \& Vehrencamp 1999). It is classified as 'repeat/ eventual variety' such as 'stereotyped/ alternative mode' of singing in Indian Robin, and 'serial/ immediate variety' analogue to 'complex mode' of singing in present study. Previous studies showed that in some species singers increase their switching rate among song types during agonistic conflicts and on the arrival of female (Kramer et al. 1985; Langmore 1997). In the present study it seems that Indian Robin used the stereotyped mode of singing in low territorial pressure situations (where conspecific territorial neighbors were absent) and the alternative mode in relatively high territorial pressure situations (when the singing male had a conspecific neighbour). Although not substantiated conclusively in the present study, it opens scope to test this hypothesis in future studies.

In the present study, it was observed that the Indian Robin mostly sing in morning and evening hours, like many other passerines (Catchpole \& Slater 1995). Catchpole (1973) studied the diurnal rhythms of song production in two European Acrocephalus species, the Reed (A. scirpaceus) and Sedge (A. schoenobaenus) warblers. He observed a marked peak of singing activity around dawn and dusk in these species. The acoustic transmission hypothesis (ATH) predicts that birds sing their full songs most intensively at dawn because this is the time of the day when these songs propagate most effectively and hence should be most 
effective for long-range communication (Henwood \& Fabrik 1979). However, experiments made by Dabelsteen \& Mathevan (2002) on Blackcap Sylvia atricapilla in temperate deciduous forests, indicate that the dawn singing can't be understood only by ATH, some other factors such as feeding and social conditions may also be responsible for dawn singing. I am unable to contribute to these ideas but the Indian Robin can be a suitable model to test the ATH in tropical habitats in future studies.

\section{Song categories and functions}

On the basis of acoustical features and context of production, two categories of songs were emerged in Indian Robin. Type-A songs were simple, stereotyped, spontaneous and common, while type-B songs were rare, female oriented and more complex (MannWhitney U-test; $\mathrm{U}=8.5, \mathrm{p}<0.001$ ) than type-A. In such a manner, two or more acoustically distinct song classes have been reported for some passerine birds (namely Dark-eyed Juncos, Titus 1998; Field Sparrow Spizella pusilla, Nelson \& Croner 1991; Yellow-throated Vireo Vireo flavifrons, Smith et al. 1978; Yellow-rumped Caciques Cacicus cela, Trainer 1987; Red-vented Bulbul Pycnonotus cafer, Kumar 2004; Oriental Magpie Robin, Kumar 2003). In some species, such as European Blackbird Turdus merula (Dabelsteen \& Pedersen 1990), European Robin (Dabelsteen et al. 1997), Lesser Whitethroat Sylvia communis (Balsby 2000) and Song Sparrow Melospiza melodia (Anderson et al. 2008), songs are described as 'broadcast songs' (type-A songs of Indian Robin) and 'soft songs' (type-B songs of Indian Robin) also termed as 'quiet song', 'twitter song' or 'whisper song' in previous studies (Anderson et al. 2008). Like the Indian Robin, the first category songs of these species were loud and conspicuous and second category songs were soft, low amplitude and rare, used in different contexts such as female courtship, male-male aggression or both (Dabelsteen et al. 1998; Titus 1998; Anderson et al. 2008). However, in Indian Robin, type-B songs were used only for mating/ courtship purpose but the scope of present study limits us from discounting this feature for other functions in other seasons. Some species of North American wood-warblers (Parulidae) also sing two categories of songs. The first category songs of these species were often simple and highly stereotyped, sung at relatively low rates and near females. While, second category songs were usually more complex and variable, sung at higher rates and in male-male interactions (Spector 1992; Bolsinger 2000). In contrast with wood-warblers song system, in the present study, Indian Robin used simple and stereotyped songs for territory/pair-bond maintenance and, complex and varied songs for mating.

Some hypotheses have been proposed to explain the proliferation of song categories in birds (Nelson \& Croner 1991). It is hypothesized that all song types (phrases) within the vocal repertoire of a species may have the same purpose. Evolution of large numbers of song types in a species may be favored by both inter- and intra-sexual selection. Large repertoires may effectively repel the rival males by appearing to represent the presence of several singing males. Large repertoires might also be favored by females during mate selection (Catchpole 1980). Another hypothesis assumes that different song categories/ song types within a repertoire contain different information (Smith et al. 1978; Trainer 1987). Different song types are sung in different behavioural contexts, and thus appear to provide different information to listeners. In the present study, the Indian Robin used two categories of songs in different behavioural contexts; it seems that second class hypothesis may fit to understand the evolution of song in this species.

\section{CONCLUSION}

Studies carried out during the last five decades on the quantification of complexity and variability in bird song provides deep insights in understanding the evolution of song and sexual selection in temperate birds. It is now well-understood that the complexity of songs in passerines play an important conceptual, theoretical and empirical role. Studies on the singing behaviour of Indian birds are restricted to comparatively few species. It is believed that most tropical birds exhibit quite different social systems than temperate species. Communication systems of most Indian birds cannot be properly understood based only on the information available from temperate birds. So, extensive long-term investigations are needed for the characterisation and documentation of the vocal repertoire of Indian birds to understand the evolution of song in these species. The present study is a base- 
line effort in this direction and may possibly enable more detailed studies to be carried out in the future, especially on repertoire size, individual variations, regional dialects, and ecological and behavioural constrains on the evolution of song in Indian birds.

\section{REFERENCES}

Ali, S. \& S.D. Ripley (1983). Handbook of the Birds of India and Pakistan. Oxford University Press, Delhi, xiii+737pp.

Anderson, R.C., W.A. Searcy, S. Peters \& S. Nowicki (2008). Soft song in Song Sparrows: acoustic structure and implications for signal function. Ethology 114: 662-676.

Balsby, T.J.S. (2000). The function of song in Lesser Whitethroats Sylvia communis. Bioacoustics 11: 17-30.

Baptista, L.F. (1975). Song dialects and demes in sedentary populations of the White-crowned Sparrow (Zonotrichia leucophrys nuttalli). University of California Publications in Zoology 105: 1-52.

Bay, M.D. (1999). The type B song of the Northern Parula: structure and geographic variation along proposed subspecies boundaries. Wilson Bulletin 111(4): 505-514.

Beresford, P. \& J. Cracraft (1999). Speciation in African Forest Robins (Stiphrornis): species limits, phylogenetic relationships, and molecular biogeography. American Museum Novitates 3270: 1-22.

Bhatt, D., A. Kumar, Y. Singh \& R.B. Payne (2000). Territorial songs and calls in Oriental Magpie Robin Copsychus saularis. Current Science 78(6): 722-728.

Bjerke, T.K. \& T.H. Bjerke (1981). Song dialects in the Redwing Turdus iliacus. Ornis Scandinavica (Scandinavian Journal of Ornithology) 12: 40-50.

Bolsinger, J.S. (2000). Use of two song categories by Goldencheeked Warblers. Condor 102: 539-552.

Borror, D.J. (1981). The songs and singing behaviour of the Red-eyed Vireo. Condor 83: 217-228.

Catchpole, C.K. (1973). The functions of advertising song in the Sedge Warbler (Acrocephalus schoenobaenus) and Reed Warbler (A. scirpaceus). Behaviour 46: 300-320.

Catchpole, C.K. (1976). Temporal and sequential organization of song in the Sedge Warbler(Acrocephalus schoenobaenus). Behaviour 59: 226-246.

Catchpole, C.K. (1980). Sexual selection and the evolution of complex songs among European warblers of the genus Acrocephalus. Behaviour 74: 149-166.

Catchpole, C.K. \& P.J.B. Slater (1995). Bird Song: Biological Themes and Variations. Cambridge University Press, Cambridge, viii $+248 p$.

Dabelsteen, T., P.K. McGregor, J. Holland, J.A. Tobias \& S.B. Pedersen (1997). The signal function of overlapping singing in male robins. Animal Behaviour 53: 249-256.

Dabelsteen, T., P.K. McGregor, H.M. Lampe, N.E. Langmore \& J. Holland (1998). Quiet song in song birds: an overlooked phenomenon. Bioacoustics 9: 89-105.
Dabelsteen, T. \& S.B. Pedersen (1990). Song and information about aggressive responses of blackbirds Turdus merula - evidence from interactive playback experiments with territory owners. Animal Behaviour 40: 1158-1168.

Dabelsteen, T. \& N. Mathevan (2002). Why do songbirds sing intensively at dawn? A test of the acoustic transmission hypothesis. Acta ethologica 4: 65-72.

del Hoyo, J., A. Elliot \& D. Christie (2006). Handbook of the Birds of the World. Volume 11: Old World Flycatchers to Old World Warblers. Lynx Edicions, Barcelona, Spain, $798 \mathrm{pp}$.

Falls, J.B. (1978). Bird song and territorial behaviour, pp. 6169. In: Krames, L., P. Plinet \& T. Alloway (eds). Advances in the Study of Communication and Affect: Aggression, Dominance and Individual Spacing. Vol. 4, Plenum Press, New York, 173pp.

Garamszegi, L.Z. \& A.P. Møller (2004). Extrapair paternity and evolution of bird song. Behavioural Ecology 15: 508519.

Grimes, L.G. (1974). Dialects and geographical variation in the song of the Splendid Sunbird Nectarinia coccinigaster. Ibis 116: 314-329.

Grimmett, R., C. Inskipp \& T. Inskipp (1998). Birds of the Indian Subcontinent. Oxford University Press, Mumbai, 888pp.

Henwood, K. \& A. Fabrick (1979). A quantitative analysis of the dawn chorus: temporal selection for communicatory optimization. American Naturalist 114: 260-274.

Hesler, N., R. Mundry \& T. Dabelsteen (2011). Does song repertoire size in Common Blackbirds play a role in an intra-sexual context? Journal of Ornithology 152(3): 591601.

Highsmith, R.T. (1989). The singing behaviour of Goldenwinged Warblers. Wilson Bulletin 101: 36-50.

Hoelzel, A.R. (1986). Song characteristics and response to playback of male and female robins (Erithacus rubecula). Ibis 128: 115-127.

Hoelzel, A.R. (1989). Territorial behaviour of the robin, Erithacus rubecula: the importance of vegetation density. Ibis 131: 432-436.

Howard, R.D. (1974). The influence of sexual selection and interspecific competition on Mockingbird song (Mimus polyglottos). Evolution 28: 428-438.

Ince, A.S. \& P.J.B. Slater (1985). Versatility and continuity in the songs of thrushes Turdus spp. Ibis 127: 355-364.

Kramer, H.G., R.E. Lemon \& M.J. Morris (1985). Song switching and agonistic stimulation in the Song Sparrow (Melospiza melodia): Five tests. Animal Behaviour 33: 135-149.

Krebs, J., R. Ashcroft \& M. Webber (1978). Song repertoires and territory defense in the Great Tit. Nature 271: 539542.

Kroodsma, D.E. (1981). Geographical variation and functions of song types in warblers (Parulidae). Auk 98: 743-751.

Kroodsma, D.E. \& J. Verner (1987). Use of song repertoires among Marsh Wren populations. Auk 104: 63-72. 
Kroodsma, D.E. \& L.D. Parker (1977). Vocal virtuosity in the Brown Thrasher. Auk 94: 783-785.

Kroodsma, D.E., R.C. Bereson, B.E. Byers \& E. Minear (1989). Use of song types by the Chestnut-sided Warbler: Evidence for both intra- and inter-sexual functions. Canadian Journal of Zoology 67: 447-456.

Kumar, A. (2003). Acoustic communication in birds: Differences in songs and calls, their production and biological significance. Resonance 8(6): 44-55.

Kumar, A. (2004). Acoustic communication in the Red-vented Bulbul Pycnonotus cafer. Anais de Academia Brasileira de Ciencias (Annals of the Brazilian Academy of Sciences) 76(2): 350-358.

Kumar, A. \& D. Bhatt (2001). Characteristics and significance of calls in Oriental Magpie Robin. Current Science 80(1): 77-82.

Kunc, H.P., V. Amrhein \& M. Naguib (2005). Acoustic features of song categories and their possible implications for communication in the Common Nightingale (Luscinia megarhynchos). Behaviour 142: 1083-1097.

Kipper, S., R. Mundry, H. Hultsch \& D. Todt (2004). Longterm persistence of song performance rules in nightingales (Luscinia megarhynchos): a longitudinal field study on repertoire size and composition. Behaviour 141: 371-390.

Lambrechts, M.M. (1996). Organisation of birdsong and constraints on performance, pp. 305-319. In: Kroodsma, D.E. \& E.H. Miller (eds). Ecology and Evolution of Acoustic Communication in Birds. Cornell University Press, New York, 587pp.

Langmore, N.E. (1997). Song switching in monandrous and polyandrous Dunnocks Prunella modularis. Animal Behaviour 53: 757-766.

Marler, P. \& H. Slabbekoorn (2004). Nature's Music: The Science of Birdsong. Elsevier Academic Press, San Diego, USA, xvi+497pp.

Martin-Vivaldi, M., J.G. Martinez, J.J. Palomino \& M. Soler (2002). Extrapair paternity in the Hoopoe Upupa epops: an exploration of the influence of interactions between breeding pairs, non-pair males and strophe length. Ibis 144: 236-247.

Molles, L.E. \& S.L. Vehrencamp (1999). Repertoire size, repertoire overlap, and singing modes in the Banded Wren (Thryothorus pleurostictus). Auk 116(3): 677-689.

Nelson, D.A. \& L.J. Croner (1991). Song categories and their functions in the Field Sparrow (Spizella pusilla). Auk 108: 42-52.

Neuschulz, F. (1986). Zum Gesang des männlinchen un weiblichen Brachpiepers Anthus campestris. Journal of Ornithology 127: 514-515.

Nirmala, Sr.T. \& L. Vijayan (2003). Breeding behaviour of the Indian Robin Saxicoloides fulicata in the Anaikatty hills, Coimbatore, pp. 43-46. In: Proceedings of $28^{\text {th }}$ ESI Conference, Feb. 7-8, 2003, KMTR, Tirunelveli, India.

Osiejuk, T.S., J. Grzybek \& P. Tryjanowski (2007). Song structure and repertoire sharing in the Tawny Pipit Anthus campestris in Poland. Acta Ornithologica 42(2): 157-165.
Ryan, M.J. \& E.A. Brenowitz (1985). The role of body size, phylogeny, and ambient noise in the evolution of bird song. American Naturalist 126: 87-100.

Schmidt, B.K., J.T. Foster, G.R. Angehr, K.L. Durrant \& R.C. Fleischer (2008). A new species of African Forest Robin from Gabon (Passeriformes: Muscicapidae: Stiphrornis). Zootaxa 1850: 27-42.

Scriba, M.F. \& W. Goymann, (2010). European robins (Erithacus rubecula) lack an increase in testosterone during simulated territorial intrusions. Journal of Ornithology 151: 607-614.

Slabbekoorn, H., J. Ellers \& T.B. Smith (2002). Birdsong and sound transmission: The benefits of reverberations. Condor 104: 564-573.

Slater, P.J.B. (1981). Chaffinch song repertoires: observations, experiments and a discussion of their significance. Zeitschrift fur Tierzuchtung und Zuchtungsbiologie (Journal of Animal Breeding and Genetics) 56: 1-24.

Slater, P.J.B. (1983). Sequences of song in chaffinches. Animal Behaviour 31: 272-281.

Smith, W.J., J. Pawlukiewicz \& S.T. Smith (1978). Kinds of activities correlated with singing patterns of the Yellowthroated Vireo. Animal Behaviour 26: 862-885.

Spector, D.A. (1992). Wood-warbler song systems. A review of paruline singing behaviours, pp. 199-238. In: Power, M.D. (ed). Current Ornithology. Plenum Press, New York, 238pp.

Staicer, C.A. (1989). Characteristics, use and significance of two singing behaviours in Grace's Warbler (Dendroica graciae). Auk 106: 49-63.

Titus, R.C. (1998). Short-range and long-range songs: Use of two acoustically distinct song classes by Dark-eyed Juncos. Auk 115(2): 386-393.

Trainer, J.M. (1987). Behavioural associations of song types during aggressive interactions among male Yellow-rumped Caciques. Condor 89: 731-738.

Wallschlager, D. (1980). Correlation of song frequency and body weight in passerine birds. Experientia 36: 412.

Welling, P.P., S.O. Rytkonen, K.T. Koivula \& M.I. Orell (1997). Song rate correlates with parental care and survival in Willow Tits: advertisement of male quality? Behaviour 134: 891-904.

Williams, L. \& M.H. MacRoberts (1977). Individual variation in the songs of Dark-eyed Juncos. Condor 79: 106-112.

Justification for delayed publication:

During 2005, I was selected as a scientist in the ZSI and posted at Itanagar, Arunachal Pradesh for about five years. The lack of bio-acoustic facilities and relevant literature in the early phase of my posting, and prolonged illness of two family members led to the delay in publication -- Anil Kumar (author).

The song characteristics and functions of the species do not change in ten years. There are no new studies on this topic and therfore the findings are informative and provide a base line for the song features of the species -- Aziz Aslan (subject editor). 